\title{
EFFECT OF MELATONIN ON THE LEVEL OF THYROTROPIC HORMONES IN EXPERIMENTAL HYPOTHYROIDISM IN RATS
}

\author{
Elbekyan K. S., Markarova E. V., Khodzhayan A. B., Gevandova M. G.
}

Stavropol State Medical University, Russian Federation

\section{ВАИЯНИЕ МЕААТОНИНА НА УРОВЕНЬ ТИРЕОТРОПНЫХ ГОРМОНОВ ПРИ ЭКСПЕРИМЕНТААЬНОМ ГИПОТИРЕОЗЕ У КРЫС}

\author{
К. С. Э^ьбекьян, Е. В. Маркарова, А. Б. ХоАжаян, М. Г. ГеванАова
}

Ставропольский госуАарственный меАицинский университет, Российская ФеАерация

A laboratory rat's model was used to study the changes in the hormonal activity in the pituitary-thyroid system under the impact of melatonin given in physiological doses. It has been shown that melatonin has a stimulating effect against the background of reduced thyroid activity.

Key words: experimental model of hypothyroidism, melatonin, thyrotropic hormones, rats

На лабораторных крысах изучены изменения гормональной активности гипофизарно-тиреоидной системы под влиянием мелатонина в физиологических дозах. Показано, что на фоне пониженной тиреоидной активности мелатонин оказывает стимулирующий эффект.

Ключевые слова: экспериментальная модель гипотиреоза, мелатонин, тиреотропные гормоны, крысы

T The variety of clinical symptoms based on reduced function in the thyroid gland is largely due to metabolic disturbances related to deficit of thyroid hormones [2]. However, despite the whole arsenal of thyrotropic medications used nowadays, there is still an urgent need for replacement therapy as the medications available cannot boast of sufficient clinical efficiency and, in case used long-term, may cause side effects. This is why there a reasonable interest taken in search for newer drugs that would be capable of preventing and improving hypothyroidism $[3,5]$.

Due to its mediation activity on the verge of external illumination and the body's internal environment, as well as its pronounced chronobiological effects, the pineal gland with its hormone melatonin (MT) adopts the role of a regulator and coordinator for the entire endocrine ensemble. This is the way that peripheral glands adjust their functioning to the environmental changes $[1,4]$.

Aim of study was to investigate the impact that melatonin has on the level of thyrotropic hormones in case of experimental hypothyroidism in rats.

Material and Methods. The study was carried out on laboratory white rats, males, weighing about 200-230 g, which were divided in four groups (10 rats each). The rats in Group 1 were subjected to no impact. They were kept under feeding and living conditions similar to those of the experimental groups. In order to develop experimental hypothyroidism, the animals in the experimental groups were given thyrozol (anti-thyroid substance that ruins the thyroid gland hormones synthesis), which was introduced into their stomachs through an enteral feeding tube on a daily basis for 22 days $(200 \mathrm{mg} / \mathrm{kg}$ ). The animals of Group 3 were given melatonin alone $(0.1 \mathrm{mg} / \mathrm{kg}$, afternoon). The rats in Group 4 received the same dosage of melatonin after the development of hypothyroidism for 14 days. Blood biochemical check-up was performed prior to the experiment, and then 14,22 , and 30 days into the experiment. The animals were taken out of the experiment following the conditions for euthanasia subject to the Declaration of Helsinki on Ethical Principles for Medical Research.

The levels of triiodothyronine $\left(\mathrm{T}_{3}\right)$, free thyroxine $\left(\mathrm{fT}_{4}\right)$ and of thyrotropic hormone (TTH) were detected via the immunoenzymatic assay on the analyzer Immunochem-2100 employing the standard test sets of Alcor-Bio (Russia).

Shapiro-Wilk W test was used to analyze the distribution type correspondence to the normal distribution law [3]. Since the presented quantitative data had normal distribution, the digital stuff was statistically processed with the Student's t-test.

Results. Our study aiming at detecting thyroid activity in rats has shown that the concentration of thyroid hormones in the blood of the animals administered with thyrozol was reduced if compared to the animals of the intact group. After 22 days of introducing thyrozol, the $\mathrm{fT}_{4}$ level was $7.4 \%(\mathrm{p}<0.001), \mathrm{T}_{3}-73 \%(\mathrm{p}<0.001)$ compared to the intact group, while the TTH level went up to $126 \%$. The $\mathrm{T}_{3} / \mathrm{fT}_{4}$ coefficient was $27.8 \pm 0.7$, which proved to be 9.5 times that of the intact animals. This is indicative of hypothyroidism developing in the animals.

After ten days of introducing MT $(0.1 \mathrm{mg} / \mathrm{kg})$, the concentration of $\mathrm{fT}_{4}$ went up by $17.3 \%$, compared to the intact animals, while the levels of $\mathrm{T}_{3}$ went up by $16.8 \%$. The lack of change from the levels of $\mathrm{T}_{3} / \mathrm{fT}_{4}$ coefficient means that the increase of $T_{3}$ and $\mathrm{fT}_{4}$ in rats' blood under melatonin was corresponding (of equal value), which 
is of importance in terms of theoretical rationale behind administering of MT-based medications in case of hypothyroidism.

For explaining the mechanism of stimulating impact that MT has on the thyroid gland hormonal activity, it is important to have a look at the data related to single-time detecting of blood TTH levels, which reveal lack of any statistically significant change in the respective index. The outcomes allow concluding that melatonin has a direct impact on the thyroid gland. The reason behind such activation of the system may be found in direct stimulating effect that MT has on the thyroid parenchyma, yet also involving the specific receptors [5].

The data obtained from the group of the animals that received MT while developing hypothyroidism, were compared to the respective indices in hypothyroid rats. This showed that in hypothyroid rats a course of MT brought up the $\mathrm{fT}_{4} 15.5$ times, while the levels of $\mathrm{T}_{3}$ went up 1.8

\section{References}

1. Arushanyan E. B., Beyer E. V. Melatonin: biology, pharmacology, clinic. 2015: 395 p.

2. Claustrat B., Leston J. Melatonin: Physiological effects in humans. Neurochirurgie. 2015;61(2):77-84.

3. Esquifino A., Agrasal C., Velázquez E. Effect of melatonin on serum cholesterol and phospholipid levels, and on prolactin, thyroid-stimulating hormone and thyroid hormone levels, in hyperprolactinemic rats. Life Sci. 1997;61(11):1051-1058. times. The coefficient values went down and approached the normal rate while the TTH level was $0.12 \pm 0.01 \mathrm{mIU} / \mathrm{l}$, which was 1.4 times below that level in thyroid animals. The outcomes suggest that MT may act through the pituitary-hypothalamic axis as well.

Conclusions. Given the data above, we can say that MT has a stimulating effect when administered against reduced thyroid activity. This makes it possible to suggest that under natural conditions the pineal gland acts as a modulator for the pituitary-thyroid functioning. This role is due to uneven interactions with various components of the endocrine axis of hypothalamus - pituitary gland thyroid gland [4]. In particular, it is not impossible that the system in question is inhibited through depression of its central components with MT due to disturbed thyroliberin production by neurons of hypothalamus, as well as thyrotropic hormone by pituitary cells through the MTreceptors embedded into these structures.

4. Garcia-Marin R., Fernandez-Santos J. M., Moril-loBernal J. Melatonin in the thyroid gland: regulation by thyroid-stimulating hormone and role in thyroglobulin gene expression. J. Physiol Pharmacol. 2015;66(5):643652.

5. Vriend J., Sheppard M. S., Bala R. M. Effects of melatonin and hypothyroidism on somatomedin levels of female Syrian hamsters. J Pineal Res. 1989;7(1):85-90.

\title{
About authors:
}

Elbekyan Karine, DBS, Professor, Head of Department of General and Biological Chemistry;

tel.: +79624007045; e-mail: karinasgma@inbox.ru

Markarova Evgenia, Assistant of Department of General and Biological Chemistry; tel.: +7(8652)353683; e-mail: obiochem@stgmu.ru

Khodzhayan Anna, MD, PhD, Professor of Department of Biology; tel.: +7(8652)353442; e-mail: biology@stgma.ru

Gevandova Margarita, PhD, Associate Professor, Head of Department of Biology; tel.: +7(8652)353442; e-mail: biology@stgma.ru

(C) Group of authors, 2016

UDC 618.14:60.9/.8

DOI - http://dx.doi.org/10.14300/mnnc.2016.11044

ISSN - 2073-8137

\section{THE ROLE OF HYSTEROSCOPY IN DIAGNOSIS THE PELVIC PAIN SYNDROME CAUSED BY ADENOMYOSIS}

\author{
Orazov M. R. ${ }^{1}$, Radzinskiy V. E. ${ }^{1}$, Nosenko E. N. ${ }^{2}$ \\ ${ }^{1}$ People's Friendship University of Russia, Moscow, Russian Federation \\ 2 Odessa National Medical University, Ukraina
}

\section{РОАЬ ГИСТЕРОСКОПИИ В АИАГНОСТИКЕ ТАЗОВОЙ БОАИ, ОБУСАОВАЕННОЙ ААЕНОМИОЗОМ}

\author{
М. Р. Оразов ${ }^{1}$, В. Е. РаАзинский ${ }^{1}$, Е. Н. Носенко ${ }^{2}$ \\ ${ }^{1}$ Российский университет Аружбы народов, Москва, Российская ФеАерация \\ 2 ОАесский национаАьный меАицинский университет, Украина
}

Endometriosis, including adenomyosis, remains one of the important clinical problems of modern gynecology. To date, the diagnostic value of hysteroscopy in the detection of foci of adenomyosis varies widely depending on the shape and the extent of spreading of the pathological process. The aim of the study was to determine the diagnostic capabilities of operative hysteroscopy with adenomyosis, accompanied by the pelvic pain syndrome. 120 female patients with pelvic pain adenomyosis were included into the present study. The verification of the diagnosis of adenomyosis was made on the basis of clinical and anamnestic, objective gynecological, ultrasound, tomography data. The 